\title{
Detection of Two Orchid Viruses Using Quartz Crystal Microbalance-Based DNA Biosensors
}

\author{
Alvin Jin-Cherng Eun, Liqun Huang, Fook-Tim Chew, Sam Fong-Yau Li, and Sek-Man Wong
}

First and fifth authors: Department of Biological Sciences; second and fourth authors: Department of Chemistry; third author: Department of Pediatrics; and fourth author: Institute of Materials Research and Engineering, National University of Singapore, Kent Ridge, Singapore 117543.

Accepted for publication 6 March 2002.

\begin{abstract}
Eun, A. J.-C., Huang, L., Chew, F.-T., Li, S. F.-Y., and Wong, S.-M. 2002. Detection of two orchid viruses using quartz crystal microbalance-based DNA biosensors. Phytopathology 92:654-658.

We have developed a piezoelectric DNA-sensor based on DNA-RNA hybridization for the detection of two orchid viruses, Cymbidium mosaic virus (CymMV) and Odontoglossum ringspot virus (ORSV). Specific oligonucleotide probes modified with a mercaptohexyl group at the $5^{\prime}$ phosphate end were directly immobilized onto $10-\mathrm{MHz}$ AT-cut quartz

probes were exposed to test solutions containing viral RNA for hybridization. Various experimental conditions evaluated were (i) DNA probe coating concentration, (ii) sensitivity and specificity of the probes at different hybridization temperatures, and (iii) effects of incubation temperature on the hybridization time. The specific nucleotide probe-coated QCM-based DNA sensors were able to detect both CymMV and ORSV in quantities as low as approximately $1 \mathrm{ng}$ in purified RNA preparations and $10 \mathrm{ng}$ in the crude sap of infected orchids. This is the first application of a DNA biosensor for the detection of plant viruses.
\end{abstract} crystal microbalance (QCM). QCMs coated with such oligonucleotide
Cymbidium mosaic virus (CymMV) and Odontoglossum ringspot virus (ORSV) belong to the potexvirus and tobamovirus groups, respectively. They are two of the most prevalent and economically important orchid viruses (40), infecting numerous commercially important orchid genera, and have attained a worldwide distribution (43). CymMV induces floral and foliar necrosis while ORSV causes ring spots on leaves and color breaking on flowers. Mixed infections of both viruses can cause blossom brown necrotic streaks. The viruses also reduce plant vigor and lower flower quality, thus affecting their economic value (15). These viruses are relatively stable and are spread by contaminated tools and pots (40).

Many reliable techniques have been developed over the years for the detection of viruses in orchids (22). Serological techniques, such as the agar gel diffusion and both direct and indirect enzymelinked immunosorbent assay methods (ELISA) $(15,39,41)$, are currently used in routine diagnosis of plant virus infection. Bioassay and immunosorbent electron microscopy also have been used to examine for the presence of viruses in sap from infected plants. For the detection of viral RNA, several conventional methods have been developed in recent years. These include reverse transcription-polymerase chain reaction (RT-PCR) $(23,28$, 30), immunocapture-PCR (3), digoxigenin (DIG)-labeled cRNA probes $(16,17)$, immunocapillary zone electrophoresis (I-CZE) (9), liquid chromatography (LC)-and matrix-assisted laser desorption-ionization (MALDI)-mass spectrometry (34), TaqMan realtime RT-PCR (8), molecular beacons (10), and, most recently, quartz crystal microbalance (QCM) immunosensors (7). These methods provide highly sensitive and specific tests, but involve multiple steps in sample preparation. In addition, these procedures are time consuming.

Corresponding author: S.-M. Wong; E-mail address: dbswsm@nus.edu.sg

Publication no. P-2002-0417-01R

(C) 2002 The American Phytopathological Society
The QCM is a sensitive mass-measuring device consisting of a quartz crystal wafer sandwiched between two metal electrodes which are connected to an external oscillator circuit that records the resonant frequency. The resonance frequency decreases upon the increase of a given mass, as shown in the Sauerbrey equation (29): $\Delta F=-2 F_{0}{ }^{2} \Delta M / A\left(\rho_{q} \mu_{q}\right)^{1 / 2}$, where $\Delta F$ is the measured frequency shift, $F_{0}$ is the fundamental crystal frequency, $A$ is the coated area , $\Delta M$ is the mass change due to surface deposition, $\rho_{q}$ is the density of the quartz crystal, and $\mu_{q}$ is the shear modulus.

In this study, we used a QCM method to detect plant viruses based on DNA-RNA hybridization. Oligonucleotide probes were immobilized on a QCM which bound to complementary target viral RNA of two orchid viruses, CymMV and ORSV, present within the crude sap of infected orchids.

\section{MATERIALS AND METHODS}

CymMV and ORSV RNA purification. CymMV and ORSV were propagated and purified as previously described $(9,10)$.

CymMV and ORSV CP DNA probes. Two single-stranded DNA probes complementary to the CymMV and ORSV genes encoding coat proteins (CPs) were designed and synthesized (Genset Oligos, Singapore) based on the viral sequences determined previously $(6,42)$. Each probe was $25 \mathrm{nt}$ in length and possessed a mercaptohexyl group attached to its $5^{\prime}$-phosphate terminal. The sequences of the CymMV probe (oligo-CymMV-CP: melting temperature $\left[T_{m}\right]=65^{\circ} \mathrm{C}, \% \mathrm{GC}=52$, sequence $=5^{\prime}$-[Thiol $] \mathrm{GGG}$ TTA TGG CCT TGA TTT CTT CGG C-3') and ORSV probe (oligo-ORSV-CP: $T_{m}=55^{\circ} \mathrm{C}, \% \mathrm{GC}=40$, sequence $=5^{\prime}$-[Thiol $]$ CTT GTT GTG TTT GGA ACT GAT TAC C-3') were similar to the loop sequences of the molecular beacons MCM-CP and MOR$\mathrm{CP}$, respectively, as previously reported (10). The oligo-ORSV-CP probe sequence corresponded to positions 5817 to 5841 of the ORSV CP gene, while the oligo-CymMV-CP probe sequence corresponded to positions 5600 to 5625 of the CymMV CP gene.

QCM and frequency counter. Circular AT-cut $10 \mathrm{MHz}$ QCMs with gold electrodes on either face were used (International Crys- 
tal Manufacturing Co. Inc., Oklahoma City, OK) for our experiments. Each QCM was $14 \mathrm{~mm}$ in diameter and $0.2 \mathrm{~mm}$ thick, while the gold electrodes were $5.1 \mathrm{~mm}$ in diameter and $100 \mathrm{~nm}$ thick. A laboratory-constructed transistor-transistor logic integrated circuit (TTL-IC) based on IC 74LS504 was used to power the quartz crystals. A TF830 universal frequency counter (ThurlbyThandar Instruments, Ltd., Huntingdon, Cambridgeshire, U.K.) was used to measure their output frequency. All frequency readings were recorded at room temperature.

DNA probe immobilization. Hot Piranha solution (concentrated $\mathrm{H}_{2} \mathrm{SO}_{4}$ : $30 \% \mathrm{H}_{2} \mathrm{O}_{2}, 3: 1$, vol/vol) $(10 \mu \mathrm{l})$ was applied for 5 min to both sides of the gold electrode surface of QCMs pretreated with ( $\gamma$-aminopropyl)-triethoxysilane (APTES) (Fluka, Buchs, Switzerland) as previously described (7). The quartz crystals then were rinsed with distilled water followed with ethanol, air dried, and the initial resonance frequency $\left(F_{0}\right)$ recorded. This procedure was repeated twice. Five microliters each of oligo-

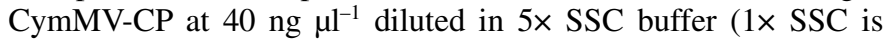
$0.15 \mathrm{M} \mathrm{NaCl}$ plus 0.015 sodium citrate) (300 mM sodium chloride, $30 \mathrm{mM}$ sodium citrate), $\mathrm{pH} 7.0$, was applied on both sides of the quartz crystals for $24 \mathrm{~h}$ at room temperature. A rinsing step with $0.1 \mathrm{M}$ glycine in $20 \mathrm{mM}$ phosphate-buffered saline (PBS), $\mathrm{pH}$ 7.0, was performed after oligo-CymMV-CP incubation to block unreacted aldehyde groups. All quartz crystals subsequently were rinsed three times with $5 \times$ SSC buffer, $\mathrm{pH}$ 7.0, followed with distilled water to remove salt deposits and excess nucleic acid probes. ORSV QCM DNA biosensors were prepared using the same procedure and concentration of oligo-ORSV-CP. The QCM DNA biosensors were air dried and their resonance frequency $\left(F_{1}\right)$ read and recorded. All biosensors were stored at $4^{\circ} \mathrm{C}$ for use in subsequent experiments.

Optimization of incubating DNA probe concentrations. Five microliters each of oligo-CymMV-CP at dilutions of 12, 18, 37,

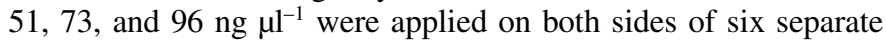
groups of APTES pretreated QCMs, each group consisting of three QCMs. The QCMs then were treated as described in the previous section and the average frequency shifts calculated. The same procedure was repeated for oligo-ORSV-CP at dilutions of

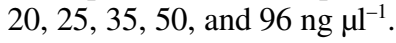

Effect of temperature on the specificity and sensitivity of QCM DNA biosensors. Five microliters each of purified CymMV RNA at dilutions of $0.05,0.12,0.23,0.30,0.45$, and $0.90{\mathrm{ng} \mathrm{l}^{-1}}^{-}$ were applied on both sides of six separate groups of oligo-CymMVCP QCMs, with each group consisting of four QCMs. Within each group, two QCMs were incubated at room temperature $\left(25^{\circ} \mathrm{C}\right)$ while the rest were incubated at temperatures $10^{\circ} \mathrm{C}$ below the $T_{m}$ $\left(55^{\circ} \mathrm{C}\right)$. After an incubation period of $1 \mathrm{~h}$, the QCMs were rinsed three times with $5 \times$ SSC buffer, $\mathrm{pH}$ 7.0, followed by distilled water, and the average frequency shifts were calculated. This procedure was repeated using purified ORSV RNA to determine the specificity of the oligo-CymMV-QCM. Similar procedures were performed to determine the effect of temperature on the sensitivity and specificity of the oligo-ORSV-CP QCMs.

Effect of temperature on the optimal hybridization time of

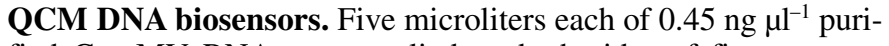
fied CymMV RNA were applied on both sides of five separate groups of oligo-CymMV-CP QCMs, each group consisting of four QCMs. Within each group, two QCMs were incubated at room temperature $\left(25^{\circ} \mathrm{C}\right)$ while the rest were incubated at temperatures $10^{\circ} \mathrm{C}$ below the $T_{m}\left(55^{\circ} \mathrm{C}\right)$. At time points of $30,60,90$, and 130 min after the start of hybridization, one QCM group was rinsed as described above and the average frequency shifts calculated. Similar procedures were performed to determine the effect of temperature on the optimal hybridization time of the oligoORSV-CP QCMs using time points of 20, 40, 60, 90, and $130 \mathrm{~min}$. Each experiment was carried out three times.

QCM detection of viruses from infected crude saps. Fresh leaf samples of healthy, CymMV- and ORSV-infected orchid
Oncidium $(0.5 \mathrm{~g}$ each) were ground in $1 \mathrm{ml}$ of $0.01 \mathrm{M}$ sodium borate buffer, $\mathrm{pH}$ 7.5. The homogenate was centrifuged at low speed to remove plant debris. This supernatant was diluted 100-

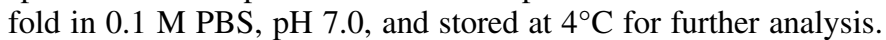
Healthy crude sap samples $(5 \mu \mathrm{l})$ were applied on both sides of five oligo-CymMV-CP QCMs and incubated at room temperature $\left(25^{\circ} \mathrm{C}\right)$ for $1 \mathrm{~h}$. The QCMs subsequently were rinsed as described above and the average frequency shifts calculated. This procedure was repeated using CymMV- and ORSV-infected crude sap samples using separate groups of five oligo-CymMV-CP QCMs. The oligo-ORSV-QCMs were tested using the same protocol.

\section{RESULTS}

Optimization of incubating DNA probe concentrations. The frequency shift by the oligo-CymMV-CP QCM significantly increased from 95 to $260 \mathrm{~Hz}$ when the oligo-CymMV-CP concentration was increased from 12 to $37 \mathrm{ng} \mathrm{\mu l}^{-1}$ (Fig. 1). Similar increase in the frequency shift was observed in the oligo-ORSV-CP QCM from 175 to $280 \mathrm{~Hz}$ (Fig. 1) when the oligo-ORSV-CP concentra-

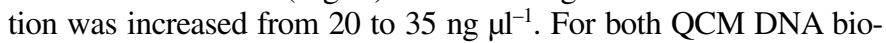
sensors, no significant increases in frequency shifts were observed when the DNA probe concentrations above $40 \mathrm{ng} \mathrm{\mu l}^{-1}$ were used.

Effect of temperature on the specificity and sensitivity of QCM DNA biosensors. Upon incubation of the oligo-CymMV$\mathrm{CP}$ QCMs with increasing concentrations of purified CymMV RNA at room temperature $\left(25^{\circ} \mathrm{C}\right)$, the frequency shifts increased significantly from 50 to $325 \mathrm{~Hz}$, corresponding to purified

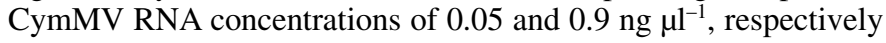
(Fig. 2A). Incubations at high temperature $\left(55^{\circ} \mathrm{C}\right)$ resulted in a similar profile, which tapered off at a maximal frequency shift of

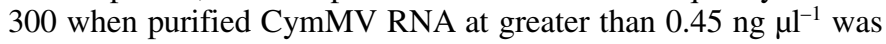
used (Fig. 2A). Regardless of the incubation temperature, minimal increases in frequency were observed when the oligo-CymMV-CP QCM was incubated with purified ORSV RNA (Fig. 2A). Similar observations were recorded for the oligo-ORSV-CP QCMs. Incubations at $25^{\circ} \mathrm{C}$ resulted in much larger frequency shifts than those at $44^{\circ} \mathrm{C}$, yielding maximum frequency shifts of 360 and $295 \mathrm{~Hz}$,

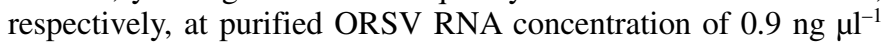
(Fig. 2B). Regardless of the incubation temperature, minimal increases in frequency were observed with purified ORSV RNA concentrations above $0.45 \mathrm{ng} \mu \mathrm{l}^{-1}$ and when purified CymMV RNA was used as the target nucleic acid (Fig. 2B). Both QCM DNA biosensors could detect as low as $0.6 \mathrm{ng}$ per QCM side of their purified target viral RNA.

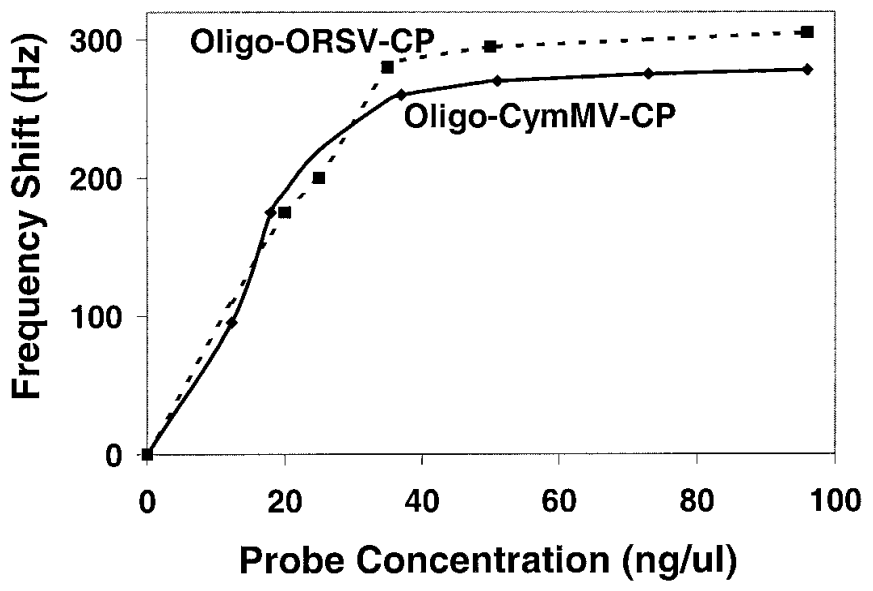

Fig. 1. Nucleic acid loading curves for oligo-Cymbidium mosaic virus (CymMV) coat protein (CP) and oligo-Odontoglossum ringspot virus (ORSV)-CP quartz crystal microbalance DNA biosensors. Each data point represents value averaged from three independent samples. The standard deviation values are too low to be plotted on the graph. 
Effect of temperature on the optimal hybridization time of QCM DNA biosensors. The rate of change in the frequency shifts differed between oligo-CymMV-CP QCMs incubated at the two temperatures $\left(25\right.$ and $\left.55^{\circ} \mathrm{C}\right)$. Maximum frequency shift $(200 \mathrm{~Hz})$ was achieved within approximately $40 \mathrm{~min}$ incubation time at $25^{\circ} \mathrm{C}$, whereas $90 \mathrm{~min}$ was required when the incubation was performed at $55^{\circ} \mathrm{C}$ (Fig. 3A). With regards to the oligo-ORSV-CP QCMs, the maximum frequency shift $(230 \mathrm{~Hz})$ was achieved within approximately $1 \mathrm{~h}$ of incubation time at both 25 and $44^{\circ} \mathrm{C}$ (Fig. 3B).

QCM detection of viruses from infected crude saps. OligoCymMV-CP QCMs exhibited significant increase in frequency shifts upon incubation with crude saps containing the target virus. Low levels of frequency shifts were observed when healthy $(7 \mathrm{~Hz})$ and ORSV-infected crude saps $(28 \mathrm{~Hz})$ were tested. The frequency shifts were approximately 18 times greater $(512 \mathrm{~Hz})$ when compared with a known negative reaction (Fig. 4). With regards to the oligo-ORSV-CP QCMs, low levels of frequency shifts were observed when healthy $(5 \mathrm{~Hz})$ and CymMV-infected crude saps $(37 \mathrm{~Hz})$ were tested. The frequency shifts were approximately nine times greater $(323 \mathrm{~Hz})$ when compared with a known negative reaction (Fig. 4). This system can detect $10 \mathrm{ng}$ of CymMV or ORSV in infected tissues of orchids (data not shown).

\section{DISCUSSION}

Nucleic acid hybridization forms the basis of numerous QCM applications for the detection and analysis of genetic materials $(20,21)$. QCM DNA biosensors have been developed for the de-

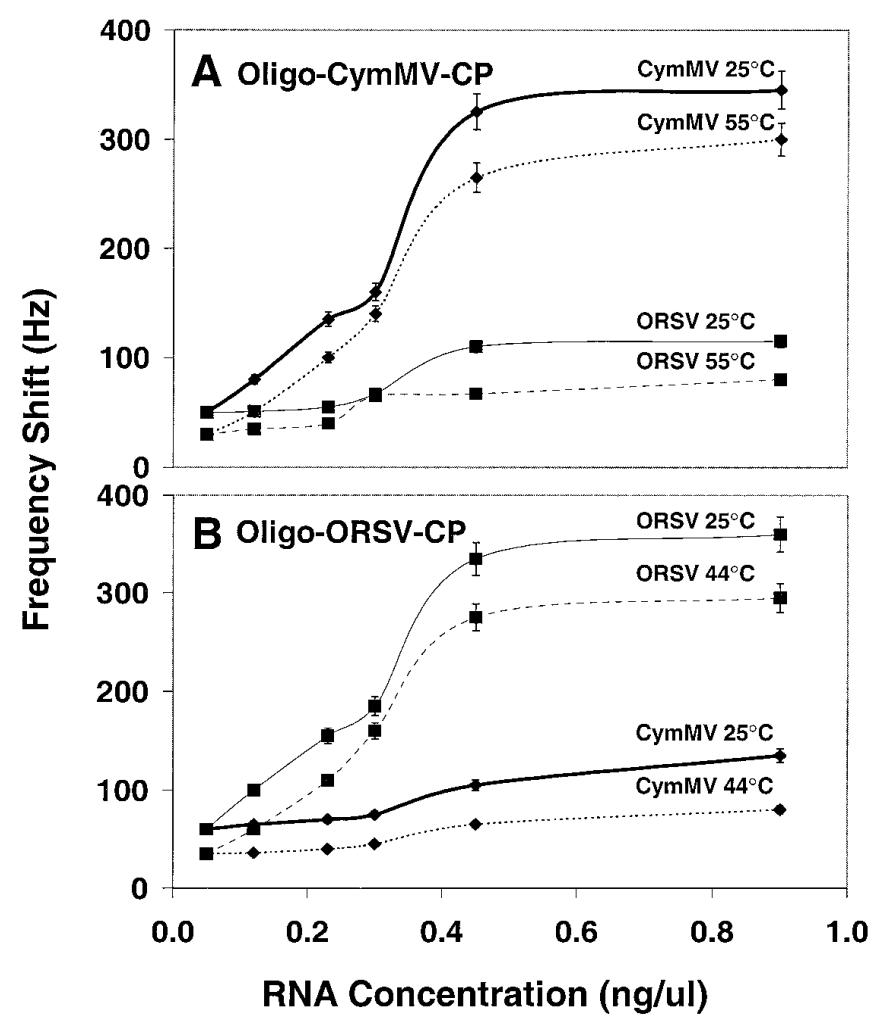

Fig. 2. Effects of temperature on the sensitivity and specificity of A, oligoCymbidium mosaic virus (CymMV) coat protein (CP) and $\mathbf{B}$, oligo-Odontoglossum ringspot virus (ORSV)-CP quartz crystal microbalance DNA biosensors upon incubation with increasing concentrations of viral RNA. Each bar at each data point represents standard deviation value averaged from four independent samples. The highest standard deviation value is $\pm 10 \mathrm{~Hz}$. Some standard deviation values are too low to be plotted on the graph. tection of bacteria such as Salmonella spp. (11) and Escherichia coli (5) and genetic disorders such as the Tay-Sach syndrome (2), as well as single base mismatches (12). Such biosensors have also been applied to probe the mechanisms of DNA UV damage (44), realtime monitoring of enzymatic cleavage of nucleic acids (37), and the kinetics of nucleic acid hybridization (31-33). Such biosensors also have been employed to monitor DNA polymerase reaction directly (25), to perform real-time monitoring of enzymatic cleavage of nucleic acids (37), and to perform mutational scanning of PCR products by subtractive oligonucleotide hybridization analysis (26). We believe this is the first report describing the use of QCM DNA biosensors for the specific detection of orchid viruses.

There are two major issues that must be dealt with in order to produce a sensitive and specific QCM DNA biosensor for the detection of the target of interest: (i) the strategy used for nucleic acid probe immobilization on the quartz crystal and (ii) the optimization of experimental conditions to minimize nonspecific hybridization. In this study, nucleic acid probe immobilization were likely via the attachment of a mercapto group (i.e., mercaptohexyl) at the $5^{\prime}$ terminals of the probes. This functional group is well known to attach strongly onto gold surfaces via chemisorption (24); this immobilization technique is widely reported to be one of the most efficient and simple immobilization methods available $(13,18)$. Using this technique, oligo-CymMV-CP and oligo-ORSV-CP were efficiently immobilized onto the quartz

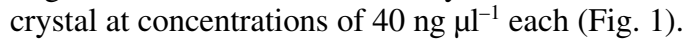

Nonspecific hybridizations were minimized in several ways. Highly conserved sequences (i.e., the $\mathrm{CP}$ genes of the two viruses) were chosen as the nucleic acid probes. The oligo-CymMV-CP

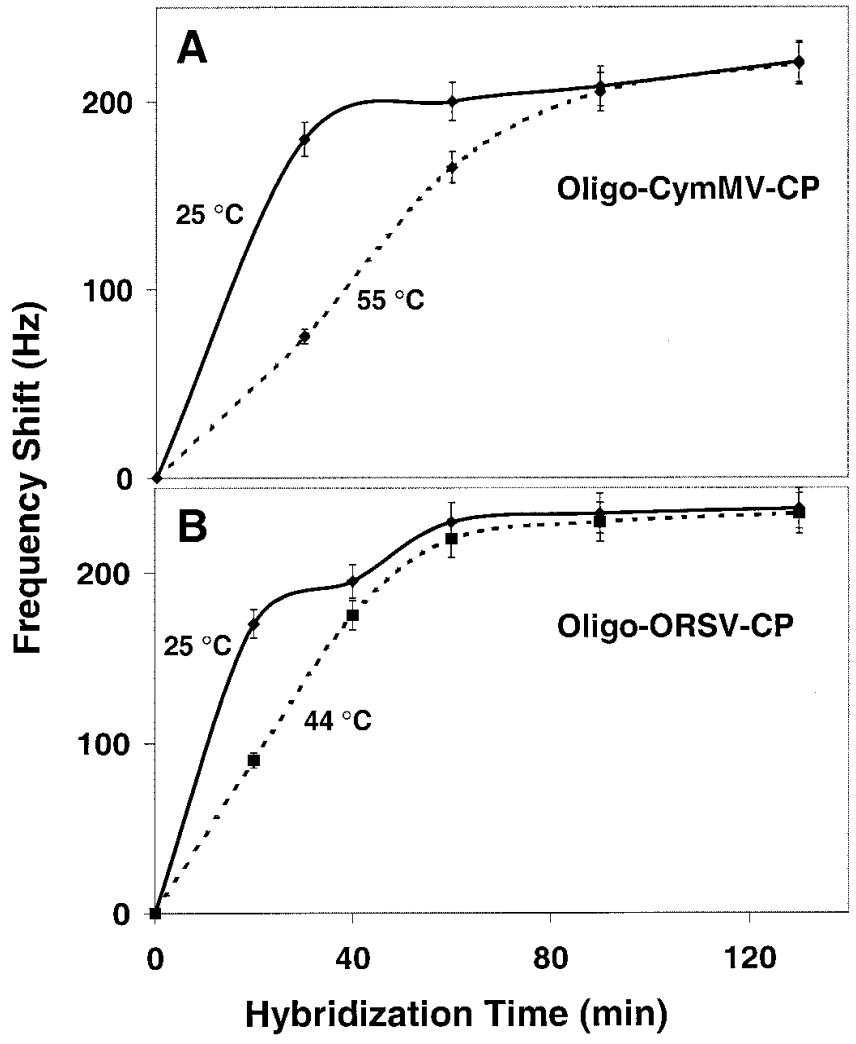

Fig. 3. Effects of temperature and hybridization time of A, oligo-Cymbidium mosaic virus (CymMV) coat protein (CP) and $\mathbf{B}$, oligo-Odontoglossum ringspot virus (ORSV)-CP quartz crystal microbalance DNA biosensors upon incubation with their respective viral RNA targets. Solid lines: incubation at $25^{\circ} \mathrm{C}$; dotted lines: incubation at high temperatures $\left(55^{\circ} \mathrm{C}\right.$ for oligo-CymMV$\mathrm{CP}$ and $44^{\circ} \mathrm{C}$ for oligo-ORSV-CP QCM biosensors). Each bar at each data point represents standard deviation value averaged from six independent samples. The highest standard deviation value is $\pm 10 \mathrm{~Hz}$. Some standard deviation values are too low to be plotted on the graph. 
and oligo-ORSV-CP QCM biosensors were highly specific, exhibiting significant increases in frequency shifts only in the presence of their target viral RNAs regardless of the incubation temperature (Fig. 2A and B). Both QCM DNA biosensors were very specific, detecting their target viral RNAs in virus-infected Oncidium orchid leaf crude saps which contained host and viral genomic and proteinaceous materials, yielding approximately 9to 18 -fold increases in frequency shifts as compared with the basal frequency shifts observed in the absence of the target viral RNAs (Fig. 4). Purification of viral RNA from crude sap of infected plants was not required. The QCM DNA biosensors were also highly sensitive, capable of detecting approximately $1.0 \mathrm{ng}$ each of purified CymMV and ORSV RNA (Fig. 2A and B), or $10 \mathrm{ng}$ each of CymMV and ORSV viruses in infected orchid samples (data not shown). While it has been shown that QCM DNA probe is able to discriminate a single nucleotide difference in target sequence recognition (32), we have not studied the tolerance for limited nucleotide mismatches in this system.

The determination of the appropriate incubation temperature is also crucial to minimize nonspecific hybridization. It was interesting to observe that the amount of nonspecific hybridization was decreased at incubation temperatures $10^{\circ} \mathrm{C}$ below the $T_{m}$ of the nucleic acid probes compared with room temperature incubations $\left(25^{\circ} \mathrm{C}\right)$ (Fig. 2A and B). Although this is desirable, there was a corresponding decrease in the maximum frequency shift upon hybridization with the target viral RNAs. Nucleic acid hybridization is a dynamic kinetic process which is highly temperature sensitive $(27,32)$. At incubation temperatures approaching the $T_{m}$

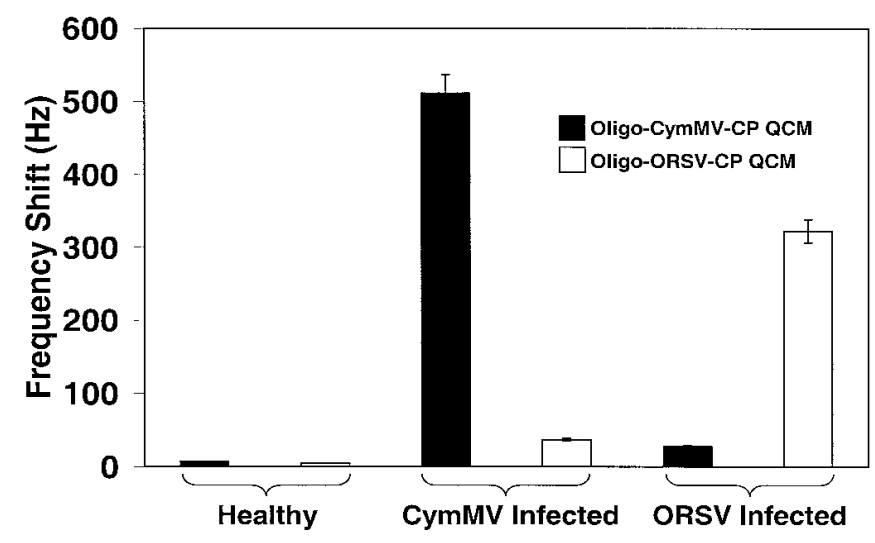

Fig. 4. Specificity of oligo-Cymbidium mosaic virus (CymMV) coat protein (CP) and oligo-Odontoglossum ringspot virus (ORSV)-CP quartz crystal microbalance DNA biosensors in the detection of target viruses in Oncidium orchid leaf crude saps. Each bar at each data point represents standard deviation value averaged from five independent samples. The highest standard deviation value is $\pm 10 \mathrm{~Hz}$. Some standard deviation values are too low to be plotted on the graph. The crude plant samples were analyzed by enzymelinked immunosorbent assay and transmission electron microscopy before the quartz crystal microbalance analysis to verify the presence of virus in infected tissue. of the probe-target duplex, the effective rate of hybridization is slow because the duplex tends to dissociate easily (Fig. 3A and B). Hybridization rates increase at lower incubation temperatures due to increases in the probe-target duplex stability (Fig. 3A and B). Thiol-derivatized peptide nucleic acids (PNAs) could be used in lieu of the $5^{\prime}$-mercaptohexyl-modified nucleic acids to lower nonspecific hybridization while maintaining optimal rates of hybridization with targeted nucleic acid molecules $(1,35)$. PNA is a DNA mimic that has a neutral peptide-like backbone with nucleobases, which allows the molecule to hybridize to complementary DNA strands with high affinity and specificity (19). Such probes have been shown to improve the distinction between closely related sequences (38). Other strategies include the use of highly branched DNA dendrimer probes (36) and multilayer DNA films (4).

The advent of novel plant virus diagnostic techniques as well as the constant improvement and refinement of current techniques are essential in light of new challenges in detecting emerging plant viruses. Benefits such as increased sensitivity, specificity, rapidity, and throughput, coupled with the potential for full automation, could significantly increase the efficiency of virus-free certification, quarantine, and epidemiological studies. Each plant virus diagnostic technique has its innate advantages and disadvantages. The properties of a few novel and current diagnostic techniques are summarized in Table 1 for comparison.

QCM biosensors offer a more economical means of plant virus detection compared with other techniques. The entire set-up of the detection system is estimated to be less than US\$2,000 (7), with most of the equipment and raw materials readily available commercially. The relative cost per sample analyzed is kept low because these biosensors do not require the use of expensive labeling reagents (e.g., radioactive isotopes, enzymes, fluorescent probes). Upon optimization of the nucleic acid immobilization techniques and hybridization times, QCM biosensors require minimal sample preparation and data is rapidly collected. Leaf crude saps can be used directly for the tests; purification of viral RNA is not necessary. The nucleic acid-based CymMV and ORSV QCM biosensors are more sensitive than the corresponding antibody-based ones (7). This could be due to the mechanism of probe and target recognition: QCM immunobiosensors possess immobilized antibodies which recognize the epitopes on the viral coat proteins, whereas QCM DNA biosensors possess immobilized nucleic acid sequences which hybridize with their complementary virus CP gene sequences. In addition, QCM DNA biosensors offer the capability of detecting specific genes of interest. It is interesting to observe that the sensitivities of the QCM DNA biosensors and that of the QCM immunosensors (7) are similar. This could be due to the fact that both detection techniques employed a similar approach. Comparing with molecular beacons, the throughput of QCM DNA biosensor is lower and the relative cost per sample analyzed is less due to no requirement for labeling of fluorescent probes. With the advent of nucleic acid arrayers coupled with the development of microelectronics, large arrays of nucleic acid probes could be immobilized onto minute quartz

TABLE 1. A comparison of a few novel and current plant virus diagnostic techniques ${ }^{\mathrm{a}}$

\begin{tabular}{|c|c|c|c|c|c|c|}
\hline Techniques & $\begin{array}{l}\text { Real-time } \\
\text { analysis }\end{array}$ & Sensitivity & Nature of probe & $\begin{array}{l}\text { Relative cost per } \\
\text { sample analyzed }\end{array}$ & Through-put & References \\
\hline QCM DNA biosensors & No & $10 \mathrm{ng}$ & Nucleic acid & Medium & $1 \mathrm{~h}$ for 30 samples & This study \\
\hline QCM immunobiosensors & No & $10 \mathrm{ng}$ & Antibody & Medium & $1 \mathrm{~h}$ for 30 samples & 7 \\
\hline TaqMan real-time RT-PCR & Yes & $5 \mathrm{fg}$ & Nucleic acid & High & $4 \mathrm{~h}$ for 96 samples & 8 \\
\hline I-CZE & Yes & $10 \mathrm{fg}$ & Antibody & Medium & 10 min for 1 sample & 10 \\
\hline DIG-labeled cRNA probes & No & $100 \mathrm{pg}$ & Nucleic acid & Medium & $4 \mathrm{~h}$ for 48 samples & 16 \\
\hline RT-PCR & No & $100 \mathrm{fg}$ & Nucleic acid & Medium & $3.5 \mathrm{~h}$ for 96 samples & 30 \\
\hline
\end{tabular}

a QCM: quartz crystal microbalance; RT-PCR: reverse transcription-polymerase chain reaction; I-CZE: immunocapture-capillary zone electrophoresis; DIG: digoxigenin; ELISA: enzyme-linked immunosorbent assay. 
crystal chips for the production of easy-to-use hand-held detectors suitable for use in the laboratory and in the field, thus providing a rapid and specific nucleic acid-based detection. QCM DNA biosensors also could be combined with a flow injection system, thus providing a real-time, high throughput and continuous assays rivaling the TaqMan real-time RT-PCR (8) and molecular beacons (10) at a fraction of their cost. This definitely will be a viable alternative for plant diagnostic clinics and field experimental stations during large-scale plant screening for virus-free certification, quarantine verification, germ plasm collection, and selection of disease resistant plants.

\section{ACKNOWLEDGMENTS}

We gratefully acknowledge the financial support from the National University of Singapore through research grant RP-154-000-070-112 and the National Science and Technology Board of Singapore for the Top-Up Scheme for A. J. C. Eun in Biomedical Engineering.

\section{LITERATURE CITED}

1. Arlinghaus, H. F., and Kwoka, M. N. 1997. Analysis of biosensor chips for identification of nucleic acids. Anal. Chem. 69:3747-3753.

2. Bardea, A., Patolsky, F., Dagan, A., and Willner, I. 1999. Sensing and amplification of oligonucleotide-DNA interactions by means of impedance spectroscopy: A route to a Tay-Sachs sensor. Chem. Commun. $1: 21-22$.

3. Barry, K., Hu, J. S., Kuehnle, A. R., and Sughii, N. 1996. Sequence analysis and detection using immunocapture-PCR of cymbidium mosaic virus and odontoglossum ringspot virus in Hawaiian orchids. J. Phytopathol. 144:179-186.

4. Caruso, F., Rodda, E., Furlong, D., Nukura, K., and Okahata, Y. 1997. Quartz crystal microbalance study of DNA immobilization and hybridization for nucleic acid development. Anal. Chem. 69:2043-2049.

5. Chen, K., Le, D., Zhang, H., Nie, L. H., and Yao, S. Z. 1996. Model of quartz crystal microbe growth sensor and its application to estimation of microbial populations in mineral waters. Anal. Chim. Acta 329:83-89.

6. Chng, C. G., Wong, S. M., Mahtani, P. H., Loh, C. S., Goh, C. J., Kao, M. C., Chung, M. C., and Watanabe, Y. 1996. The complete sequence of a Singapore isolate of odontoglossum ringspot virus and comparison with other tobamoviruses. Gene 171:155-161.

7. Eun, A. J. C., Huang, L. Q., Chew, F. T., Li, S. F. Y., and Wong, S. M. 2002. Detection of two orchid viruses using quartz crystal microbalance (QCM) immunosensors. J. Virol. Methods 99:71-79.

8. Eun, A. J. C., Seoh, M. L., and Wong, S. M. 2000. Simultaneous quantitation of two orchid viruses via the TaqMan real-time RT-PCR. J. Virol. Methods 87:151-160.

9. Eun, A. J. C., and Wong, S. M. 1999. Detection of cymbidium mosaic potexvirus and odontoglossum ringspot tobamovirus using immunocapillary zone electrophoresis. Phytopathology 89:522-528.

10. Eun, A. J. C., and Wong, S. M. 2000. Molecular beacons: A new approach to plant virus detection. Phytopathology 90:269-275.

11. Fawcett, N. C., Evans, J. C., and Chain, L. C. 1988. Nucleic acid hybridization detected by piezoelectric resonance. Anal. Lett. 21:1009-1014.

12. Furtado, L. M., and Thomson, M. 1998. Hybridization of complementary strand and single-base mutated oligonucleotides detected with an on-line acoustic wave sensor. Analyst 123:1937-1945.

13. Hashimoto, K., Ito, K., and Ishimori, Y. 1994. Sequence-specific gene detection with a gold electrode modified with DNA probes and an electrochemically active dye. Anal. Chem. 66:3830-3833.

14. Hill, J. H., Bryant, G. R., and Durand, D. P. 1981. Detection of plant virus by using purified IgG in ELISA. J. Virol. Methods 3:27-35.

15. Hu, J. S., Ferreira, S., and Wang, M. 1993. Detection of cymbidium mosaic virus, odontoglossum ringspot virus, tomato spotted virus, and potyviruses infecting orchids in Hawaii. Plant Dis. 77:464-468.

16. Hu, W. W., and Wong, S. M. 1998. The use of DIG-labeled cRNA probes for the detection of cymbidium mosaic potexvirus (CymMV) and odontoglossum ringspot tobamovirus ORSV) in orchids. J. Virol. Methods 70:193-199.

17. Hu, W. W., Wong, S. M., Loh, C. S., and Goh, C. J. 1998. Synergism in replication of cymbidium mosaic potexvirus (CymMV) and odontoglossum ringspot tobamovirus (ORSV) RNA in orchid protoplasts. Arch. Virol. 143:1265-1275.

18. Ito, K., Hashimoto, K., and Ishimori, Y. 1996. Quantitative analysis for solid-phase hybridization reaction and binding reaction of DNA binder to hybrids using a quartz crystal microbalance. Anal. Chim. Acta 327:29-35.
19. Jensen, K. K., Orum, H., Nielsen, P. E., and Norden, B. 1997. Kinetics for hybridization of peptide nucleic acids (PNA) with DNA and RNA studied with the BIAcore technique. Biochemistry 36:5072-5077.

20. Konig, B., and Gratzel, M. 1993. Development of a piezoelectric immunosensor for the detection of human erythrocytes. Anal. Chim. Acta 276:329-333.

21. Kosslinger, C., Drost, S., Albert, F., Wolf, H., Koch, S., and Woias, P. 1992. A quartz crystal biosensor for measurement in liquids. Biosens. Bioelectron. 7:397-404.

22. Lawson, R. H., and Brannign, M. 1986. Pages 2-49 in: Handbook on Orchid Pests and Diseases. American Orchid Society, West Palm Beach, FL.

23. Lim, S. T., Wong, S. M., Yeong, C. Y., Lee, S. C., and Goh, C. J. 1993. Rapid detection of cymbidium mosaic virus by the polymerase chain reaction. J. Virol. Methods 41:37-46.

24. Maeda, M., Mitsuhashi, Y., Nakano, K., and Takagi, M. 1992. DNAimmobilized gold electrode for DNA-binding drug sensor. Anal. Sci. 8:83-84.

25. Niikura, K., Matsuno, H., and Okahato, Y. 1998. Direct monitoring of DNA polymerase reaction on a quartz crystal microbalance. J. Am. Chem. Soc. 120:8537-8538.

26. Nilsson, P., Larsson, A., Lundeberg, J., Uhlen, M., and Nygren, P. A. 1999. Mutational scanning of PCR products by subtractive oligonucleotide hybridization analysis. Biotechniques 26:308-316.

27. Okahata, Y., Kawase, M., Niikura, K., Ohataka, F., Furusawa, H., and Ebara, Y. 1998. Kinetic measurements of DNA hybridization on an oligonucleotide-immobilized 27-MHz quartz crystal microbalance. Anal. Chem. 70:1288-1296.

28. Ryu, K. H., and Park, W. M. 1995. Rapid detection and identification of odontoglossum ringspot virus by polymerase chain reaction amplification. FEMS Microbiol. Lett. 133:265-269.

29. Sauerbrey, G. 1959. The use of oscillators for weighing thin layer and for microweighing. Z. Phys. 155:206-212.

30. Seoh, M. L., Wong, S. M., and Zhang, L. 1998. Simultaneous TD/RTPCR detection of cymbidium mosaic potexvirus and odontoglossum ringspot tobamovirus with a single pair of primers. J. Virol. Methods 72:197-204.

31. Su, H. B., Chong, S., and Thompson, M. 1996. Interfacial hybridization of RNA homopolymer studied by liquid phase acoustic network analysis. Langmuir 12:2247-2255.

32. Su, H. B., Chong, S., and Thompson, M. 1997. Kinetics of hybridization of interfacial RNA homopolymers studied by thickness-shear mode acoustic wave sensor. Biosens. Bioelectron. 12:161-173.

33. Su, H. B., and Thompson, M. 1995. Kinetics of interfacial nucleic acid hybridization studied by acoustic network analysis. Biosens. Bioelectron. 10:329-340.

34. Tan, W. L. S., Wong, S. M., and Kini, R. M. 2000. Rapid simultaneous detection of two orchid viruses using LC-and/or MALDI-mass spectrometry. J. Virol. Methods 85:93-99.

35. Wang, J. 1998. DNA biosensor based on peptide nucleic acid (PNA) recognition layer. A review. Biosens. Bioelectron. 13:757-762.

36. Wang, J., Jiang, M., Nilsen, T., and Getts, R. 1998. Dentritic Nucleic acid probes for DNA biosensors. J. Am. Chem. Soc. 120:8281-8282.

37. Wang, J., Jiang, M., and Palecek, E. 1999. Real-time monitoring of enzymatic cleavage of nucleic acids using a quartz crystal microbalance. Bioelectrochem. Bioenerg. 48:477-480.

38. Wang, J., Nilsson, P. E., Jiang, M., Lai, X. H., Fernandes, J. R., Douglas, H. G., Mehmet, O., Asher, B., and Michael, M. 1997. Mismatch-sensitive hybridization detection by peptide nucleic acids immobilized on a quartz crystal microbalance. Anal. Chem. 69:5200-5202.

39. Wong, S. M., and Chang, C. G. 1993. Evaluation of sample processing methods in detecting Cymbidium mosaic virus in orchids using indirect ELISA. Int. J. Trop. Plant Dis. 11:139-145.

40. Wong, S. M., Chng, C. G., Lee, Y. H., Tan, K., and Zettler, F. W. 1994. Incidence of cymbidium mosaic virus and odontoglossum Ringspot viruses and their significance in orchid cultivation in Singapore. Crop Prot. 13:235-239.

41. Wong, S. M., Lim, S. H., and Chang, C. G. 1994. Detection of odontoglossum ringspot virus and tobacco mosaic virus with homologous and heterologous antigen antibody combinations. Int. J. Trop. Plant Dis. 12:107-116.

42. Wong, S. M., Mahtani, P. H., Lee, K. C., Yu, H. H., Tan, Y., Neo, K. K., Chan, Y., Wu, M., and Chng, C. G. 1997. Cymbidium mosaic potoxvirus RNA: Complete nucleotide sequence and phytogenetic analysis. Arch. Virol. 142:383-391

43. Zettler, F. W., Ko, N. J., Wisler, G. C., Ellioit, M. S., and Wong, S. M. 1990. Viruses of orchids and their control. Plant Dis. 74:621-626.

44. Zhang, H., Tan, H. W., Wang, R. H., Wei, W. Z., and Yao, S. Z. 1998. Immobilization of DNA on silver surface of blue acoustic wave sensor and its application to the study of UV-damage. Anal. Chim. Acta 374:31-33. 